\title{
IMPLEMENTASI HARGA SAHAM SEBAGAI PEMODERASI PENGARUH FAKTOR-FAKTOR KINERJA KEUANGAN TERHADAP NILAI PERUSAHAAN
}

\author{
Supitriyani $^{1^{*}}$, Christine Pardede ${ }^{2}$, Yansen Siahaan ${ }^{3}$ \\ ${ }^{(1(2)(3)}$ Sekolah Tinggi Ilmu Ekonomi Sultan Agung \\ vitriql@gmail.com
}

\begin{abstract}
Abstrak.
Tujuan dari penelitian ini adalah: untuk mengetahui gambaran likuiditas, struktur modal, profitabilitas, dan nilai perusahaan serta pengaruh likuiditas, struktur modal, dan profitabilitas terhadap nilai perusahaan pada PT Delta Djakarta, Tbk yang terdaftar di Bursa Efek Indonesia baik secara simultan maupun parsial dengan harga saham sebagai variabel moderating. Penelitian ini dilakukan dengan metode analisis deskriptif kualitatif dan analisis deskriptif kuantitatif. Pengumpulan data dilakukan dengan metode dokumentasi. Teknik analisis yang digunakan adalah uji asumsi klasik, analisis regresi linier berganda, koefisien korelasi, koefisien determinasi, dan uji hipotesis. Hasil analisis regresi linier berganda yaitu: $\hat{Y}=-7,642-0,079 X_{1}+96,642 X_{2}+26,571 X_{3}$, berarti terdapat pengaruh negatif antara likuiditas terhadap nilai perusahaan dan terdapat pengaruh positif antara struktur modal, dan profitabilitas terhadap nilai perusahaan. Hasil analisis koefisien kolerasi dan determinasi yaitu $r=0,947$ dan nilai $r=$ 0,897. Hasil uji F menunjukkan tingkat sig > alpha $(0,001<0,05)$, berarti likuiditas, struktur modal, dan profitabilitas berpengaruh signifikan terhadap nilai perusahaan. Hasil uji t untuk likuiditas, tingkat sig > alpha $(0,461>0,05)$, berarti likuiditas tidak berpengaruh signifikan terhadap nilai perusahaan. Hasil uji t untuk struktur modal, tingkat sig > alpha $(0,069>0,05)$, berarti struktur modal tidak berpengaruh signifikan terhadap nilai perusahaan. Hasil uji t untuk profitabilitas, tingkat sig > alpha $(0,000<0,05)$, berarti profitabilitas berpengaruh signifikan terhadap nilai perusahaan. Hasil uji residual menunjukkan bahwa harga saham tidak mampu memoderasi pengaruh likuiditas, struktur modal, dan profitabilitas terhadap nilai perusahaan pada PT Delta Djakarta, Tbk yang terdaftar di Bursa Efek Indonesia
\end{abstract}

Kata kunci: Kinerja Keuangan, Nilai Perusahaan, Price

\begin{abstract}
.
The purpose of this research are: To determine the description of liquidity, capital structure, profitability, and firm value and the effect of liquidity, capital structure, and profitability on the firm value at PT Delta Djakarta, Tbk on the Indonesia Stock Excange simultaneously or partially with stock price as moderating variable. This research was conducted using qualitative descriptive analysis methods and quantitative descriptive analysis. Data collection was done by using documentation method. The analysis technique used is the classical assumption test, multiple linear regresion analysis, correlation coefficient, determanation coefficient, and hypothesis testing. The results of analysis multiple linear regression that is $\hat{Y}=-7,642-0,079 X_{1}+96,642 X_{2}+26,571 X_{3}$, meaning that there is a negative influence between liquidity on firm value and there is a positive influence between capital structure and profitability on firm value The results of the correlation and determination coefficient analysis were $r=0.947$ and the value of $R=0.897$. The results of the F test show level sig > alpha $(0.001<0.05)$, meaning that liquidity, capital structure, and profitability have a significant effect on firm value. The results of the t test for liquidity, level sig > alpha (0.461> 0.05), means that liquidity has an insignificant effect on firm value. The result of t test for capital structure, level sig $>$ alpha (0.069>0.05), means that capital structure has an insignificant effect on firm value. The results of the t test for profitability, level sig > alpha $(0.000<0.05)$, means that profitbility has a significant effect on firm value. Residual test results show that stock prices are unable to moderate the effect of liquidity, capital structure, and profitability on company value at PT Delta Djakarta, Tbk listed on the Indonesia Stock Exchange.
\end{abstract}

Keywords: Financial Performance, Firm Value, Price 


\section{PENDAHULUAN}

Persaingan dalam dunia bisnis kini berbanding lurus dengan kondisi perekonomian Indonesia pada era revolusi 4.0 yang semakin kuat. Perusahaan dituntut agar mengembangkan perusahaan, meningkatkan sumber daya manusia, dan menghasilkan laba. Tujuan utama perusahaan adalah memperoleh laba yang maksimal, sehingga dapat meningkatkan kemakmuran pemilik dan pemegang saham di masa mendatang serta mampu meningkatkan nilai perusahaan. Nilai perusahaan yang tinggi akan membuat para investor tertarik untuk berinvestasi pada perusahaan tersebut. Peningkatan nilai perusahaan merupakan hal yang sangat penting bagi perusahaan, karena nilai perusahaan merupakan cerminan dari baik buruknya kinerja perusahaan, yang akan mempengaruhi pandangan investor pada perusahaan (Y \& Amanah, 2018).

Nilai perusahaan merupakan sekumpulan rasio yang menghubungkan harga saham dengan laba serta nilai buku per saham, dimana rasio ini memberikan indikasi kepada investor dan manajemen sebuah petunjuk mengenai rancangan perusahaan di masa lalu dan prospek di masa mendatang. Harga saham yang tinggi akan membuat nilai suatu perusahaan juga tinggi. Rasio yang digunakan penulis untuk mengukur nilai perusahaan yaitu Tobin's $Q$. Rasio ini menggambarkan suatu kondisi peluang investasi atau potensi pertumbuhan perusahaan pada pasar untuk mengukur kinerja perusahaan. Meningkat dan menurunnya nilai perusahaan dapat dipengaruhi oleh beberapa faktor, salah satunya likuiditas. Likuiditas merupakan kemampuan perusahaan dalam memenuhi kewajiban jangka pendeknya melalui aset lancar. Parameter yang digunakan penulis untuk mengukur likuiditas yaitu Current Ratio (CR).

Faktor berikutnya yaitu struktur modal. Struktur modal adalah kemampuan suatu perusahaan dalam memenuhi kewajiban jangka panjangnya dengan memanfaatkan utang jangka panjang dan modal sendiri. Dalam penelitian ini, struktur modal diukur dengan parameter Long Term Debt To Equity Ratio (LTDER). Selain struktur modal, faktor lain yang mempengaruhi nilai perusahaan adalah profitabilitas. Profitabilitas adalah kemampuan perusahaan untuk menilai seberapa efisien perusahaan dalam memperoleh keuntungan atau laba dari setiap aktivitasnya. Apabila pertumbuhan profitabilitas perusahaan baik, berarti prospek perusahaan di masa depan dinilai semakin baik. Salah satu parameter yang digunakan untuk mengukur profitabilitas yaitu Return On Equity (ROE).

Objek dalam penelitian ini adalah PT Delta Djakarta, Tbk yang merupakan produsen dan distributor merek bir Jerman, di bawah merek dagang Anker. Berdasarkan laporan keuangan PT Delta Djakarta, Tbk yang telah diolah, dapat diketahui bahwa, likuiditas, profitabilitas, dan nilai perusahaan pada periode 2009-2019 mengalami fluktuasi dan cenderung meningkat, sedangkan struktur modal mengalami fluktuasi dan cenderung menurun.

Likuiditas periode 2015-2017 mengalami peningkatan sedangkan nilai perusahaan mengalami penurunan. Pada periode 2012, 2013, dan 2018 likuiditas mengalami penurunan, sedangkan nilai perusahaan mengalami peningkatan. Struktur modal periode 2010, 2012, dan 2018 mengalami penurunan sedangkan nilai perusahaan mengalami peningkatan. Pada periode 2011, 2014, 2015, dan 2017 struktur modal mengalami peningkatan sedangkan nilai perusahaan mengalami penurunan. Selain itu, profitabilitas pada periode 2011 dan 2016 mengalami peningkatan sedangkan nilai perusahaan mengalami penurunan. Pada periode 2014, 2015, dan 2017, profitabilitas mengalami penurunan yang diikuti dengan penurunan nilai perusahaan. Fenomena di atas sejalan dengan hasil penelitian yang dilakukan (Pardede et al., 2018), (Nainggolan et al., 2017), (Supitriyani et al., 2020), (Hayati et al., 2017), dan (Supitriyani, 2018).

Oleh karena itu, penelitian ini dilakukan dengan tujuan untuk mengetahui gambaran likuiditas, struktur modal, profitabilitas, dan nilai perusahaan pada PT Delta Djakarta, Tbk yang 
terdaftar di Bursa Efek Indonesia serta untuk mengetahui pengaruh likuiditas, struktur modal, dan profitabilitas terhadap nilai perusahaan pada PT Delta Djakarta, Tbk yang terdaftar di Bursa Efek Indonesia baik secara simultan maupun parsial dengan harga saham sebagai variabel moderating. Berdasarkan uraian di atas, dapat dilihat bahwa nilai perusahaan pada PT Delta Djakarta, Tbk yang terdaftar di Bursa Efek Indonesia berfluktuasi dan terdapat faktor-faktor yang mempengaruhinya.

\section{KAJIAN LITERATUR}

\section{Nilai Perusahaan}

Nilai perusahaan termasuk suatu bentuk pencapaian perusahaan yang berasal dari kepercayaan masyarakat terhadap kinerja perusahaan, dengan meningkatnya nilai perusahaan maka berdampak pada peningkatan kesejahteraan para pemilik perusahaan. Menurut (Margaretha, 2011), "nilai perusahaan merupakan rasio yang menghubungkan harga saham perusahaan dengan labanya dengan nilai buku perusahaan". Rasio ini memberikan indikasi pada manajemen petunjuk mengenai apa yang dipikirkan investor atas kinerja perusahaan di masa lalu serta prospek di masa mendatang. Jenis-jenis rasio nilai pasar adalah Price Earning Ratio (PER), Market Book Value, Rasio Q Tobin's (Tobin's Q). Faktor-faktor internal yang mempengaruhi nilai perusahaan adalah keputusan investasi, keputusan pendanaan, keputusan manajemen aset, dan pencipta nilai. (Horne, James C. Van dan John M. Wachowiccz, 2012).

\section{Kinerja Keuangan}

Kinerja keuangan merupakan salah satu komponen yang dijadikan sebagai dasar dalam menentukan kesuksesan suatu perusahaan dalam mengelola keuangannya. Kinerja keuangan merupakan sebagai penentuan ukuran-ukuran tertentu yang dapat mengukur keberhasilan suatu perusahaan dalam menghasilkan laba (Y \& Amanah, 2018). Secara umum, kinerja keuangan dapat dinilai dengan dua skala, yaitu kinerja operasi perusahaan dan kinerja pasar. Dalam penelitian ini kinerja keuangan dipandang dari sisi kinerja operasi perusahaan dilihat dari kemampuan perusahaan pada laporan keuangan yang ada dalam perusahaan yang diukur melalui likuiditas, struktur modal dan profitabilitas.

\section{Likuiditas}

Likuiditas menjadi perihal yang sangat penting bagi perusahaan karena dapat menilai seberapa besar kemampuan perusahaan dalam membayar hutang lancarnya. Likuiditas merupakan rasio yang digunakan untuk mengukur kemampuan perusahaan dalam memenuhi kewajiban jangka pendeknya (hutang jangka pendek) melalui aset lancar yang dimiliki oleh perusahaan. Jenis-jenis rasio likuiditas yang dapat digunakan untuk mengukur kemampuan perusahaan dalam memenuhi kewajiban jangka pendeknya yaitu rasio lancar (current ratio), rasio cepat (quick ratio), rasio kas (cash ratio) (Sudana, 2011). Faktor-faktor yang mempengaruhi likuiditas yaitu perusahaan tidak memiliki dana sama sekali, utang jatuh tempo, kelebihan kas secara berlimpah, pembelian aktiva tetap, volume kegiatan perusahaan, pengendalian aktiva lancar, risiko usaha, posisi pajak perusahaan, fleksibilitas keuangan, dan konservatisme atau keargresifan manajerial. 


\section{Struktur Modal}

Struktur modal menjadi perihal yang sangat penting bagi perusahaan karena baik buruknya modal akan dapat mempengaruhi kondisi keuangan perusahaan serta untuk mengetahui perbandingan hutang dengan modal yang dimiliki oleh perusahaan. Struktur modal adalah kemampuan suatu perusahaan dalam memenuhi kewajiban jangka panjangnya secara permanen dengan utang jangka panjang (liabilitas jangka panjang) dan modal sendiri yang dimiliki oleh perusahaan itu sendiri. Jenis-jenis rasio pengukuran struktur modal yaitu Debt to Asset Ratio (DAR) atau Debt Ratio (DR), Debt to Equity Ratio (DER), Long Term Debt to Equity Ratio (LTDER). Sedangkan faktor-faktor yang mempengaruhi struktur modal adalah risiko usaha, fleksibilitas finasial, tarif pajak, sikap manajemen, stabilitas penjualan, struktur aset, profitabilitas, ukuran perusahaan, posisi pajak perusahaan, dan konservatisme atau keagresifan manajerial.

\section{Profitabilitas}

Profitabilitas termasuk dimensi pengukuran kemampuan manajemen perusahaan dalam menetapkan dan melaksanakan kebijakan serta sejumlah keputusan untuk mencapai laba atau keuntungan yang telah ditargetkan. Rasio profitabilitas adalah rasio yang mengukur kemampuan perusahaan untuk menilai seberapa efisien perusahaan dalam memperoleh keuntungan atau laba dari setiap aktivitasnya. Jenis-jenis rasio profitabilitas untuk mengukur kemampuan perusahaan dalam meng-hasilkan laba adalah Gross Margin Ratio, Profit Margin Ratio, Return on Assets (ROA), Return on Equity (ROE), Return on Invesment (ROI), Earning Per Share (EPS) (Rudianto, 2013). Beberapa faktor yang mempengaruhi profitabilitas yaitu rasio likuiditas, rasio manajemen aset, rasio manajemen utang, profit margin, turn of operating assets, dividen policy, dan financial policy, dan total assets turnover.

\section{Harga Saham}

Harga saham adalah harga yang diberikan atas kepemiliki saham suatu perusahaan (Supitriyani et al., 2020). Para investor dapat mengabil keputusan pendanan dengan melihat komponen ini di bursa saham. Perusahaan yang memiliki harga saham yang stabil cenderung dianggap memiliki pondasi keuangan yang stabil pula, sehingga akan lebih dipercaya sebagai tempat untuk berinvestasi. Jenis-jenis harga saham adalah harga nominal, harga perdana, harga pasar, harga pembuka, harga penutup, harga tertinggi, harga terendah dan harga rata-rata (Widoatmodjo, 2005).

\section{Kerangka Konsep dan Hipotesis}

Kerangka konsep dalam penelitian ini adalah: 


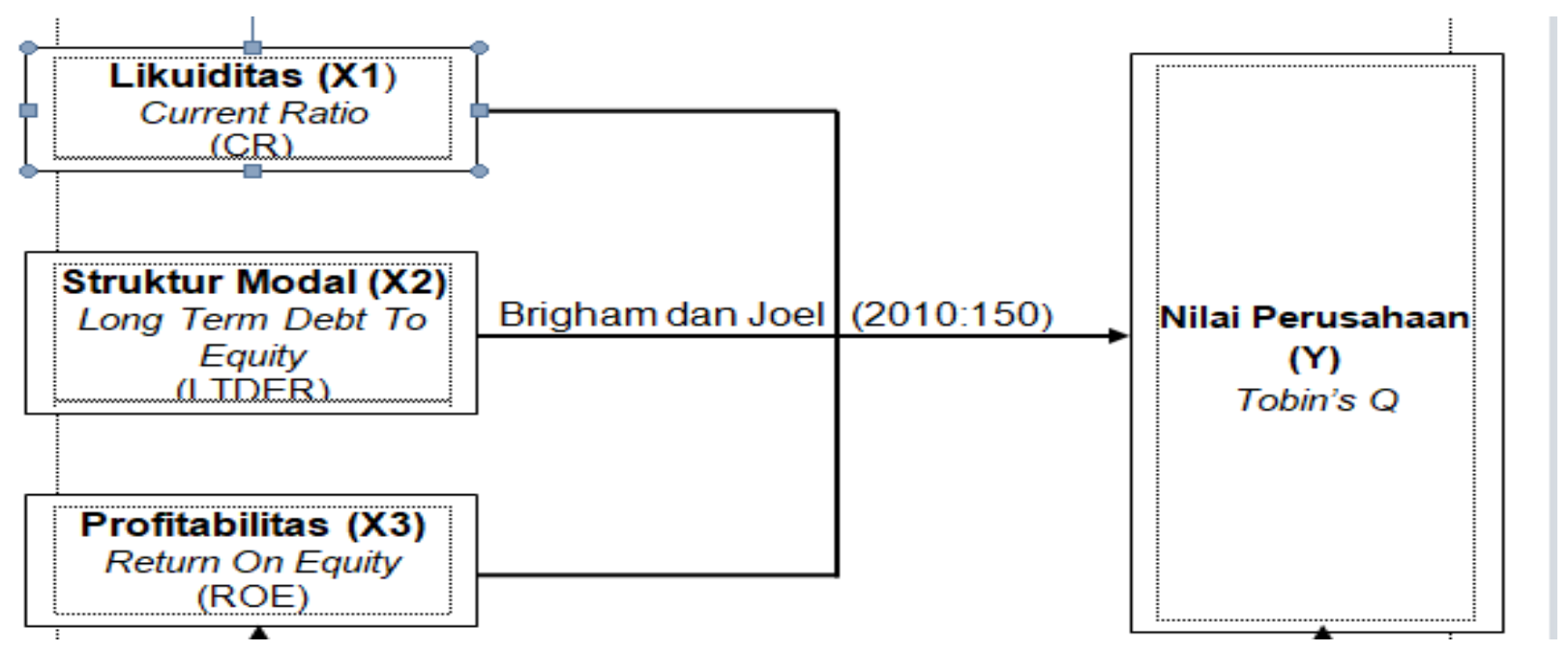

\section{Gambar 1. Kerangka Konsep}

Sedangkan hipotesis dalam penelitian ini adalah:

1. Likuiditas, struktur modal, dan profitabilitas berpengaruh terhadap nilai perusahaan baik secara simultan maupun pasial.

2. Likuiditas, struktur modal, dan profitabilitas berpengaruh terhadap nilai perusahaan baik secara simultan maupun parsial dengan harga saham sebagai variabel moderating.

\section{METODE PENELITIAN}

\section{Desain Penelitian}

Desain penelitian yang digunakan dalam penelitian ini adalah penelitian kepustakaan (library research). Penelitian kepustakaan yaitu penelitian dengan mengumpulkan berbagai data dari sumber-sumber tertentu. Data yang diperoleh dalam penelitian ini adalah data sekunder yang berbentuk teori-teori dan dilakukan langsung dengan cara membaca, mencari informasi melalui alat elektronik, mempelajari buku-buku, karangan ilmiah, catatan, serta referensi lainnya yang berhubungan dengan bahan penelitian.

\section{Objek Penelitian}

Dalam penelitian ini, penulis mengambil objek penelitian yaitu berupa laporan posisi keuangan konsolidasi, laporan laba rugi, dan laporan perubahan ekuitas PT Delta Djakarta, Tbk yang terdaftar di Bursa Efek Indonesia pada periode 2009-2019 yang telah diaudit. Untuk memperoleh data dan informasi yang diperlukan, penulis mengakses data yang bersumber dari website resmi perusahaan yaitu www.deltajkt.co.id dan juga dari website resmi Bursa Efek Indonesia yaitu www.idx.co.id

\section{Definisi Operasional Variabel}

Definisi operasional variabel berisi penjabaran setiap variabel yang ada dalam penelitian secara ringkas. Definisi operasional variabel pada penelitian ini dapat dilihat pada Tabel 1. 
Tabel 1. Definisi Operasional Variabel

\begin{tabular}{|c|c|c|c|}
\hline Variabel & Instrumen & Parameter & Skala \\
\hline $\begin{array}{l}\text { Likuiditas }\left(\mathrm{X}_{1}\right) \text { merupakan rasio } \\
\text { yang digunakan untuk mengukur } \\
\text { kemampuan perusahaan dalam } \\
\text { memenuhi kewajiban jangka } \\
\text { pendeknya melalui aset lancar } \\
\text { yang dimiliki oleh peru-sahaan. }\end{array}$ & $\begin{array}{lrr}\text { Current } & \text { Ratio } & (\mathrm{CR}) \\
\text { mengukur rasio untuk } \\
\text { mengukur } & \text { kemampuan } \\
\text { peru-sahaan membayar } \\
\text { kewajiban jangka pendek } \\
\text { atau hutang yang segera } \\
\text { jatuh tempo pada saat } \\
\text { ditagih secara kese-luruhan. }\end{array}$ & $\mathrm{CR}=\frac{\text { Aset Lancar }}{\text { Hutang Lancar }}$ & Rasio \\
\hline $\begin{array}{l}\text { Struktur Modal }\left(\mathrm{X}_{2}\right) \text { merupakan } \\
\text { kemam-puan suatu perusa-haan } \\
\text { dalam meme-nuhi kewajiban } \\
\text { jangka panjangnya secara } \\
\text { permanen dengan utang jangka } \\
\text { panjang dan modal sendiri yang } \\
\text { dimiliki oleh perusahaan itu } \\
\text { sendiri. }\end{array}$ & $\begin{array}{l}\text { Long Term Debt to Ratio } \\
\text { (LTDER) merupakan rasio } \\
\text { yang digunakan untuk } \\
\text { menghitung dengan cara } \\
\text { mem-bagi utang jangka } \\
\text { panjang dengan total } \\
\text { ekuitas. }\end{array}$ & $\begin{array}{l}\text { LTDER } \\
=\frac{\text { Hutang Jk. Panjang }}{\text { Total Ekuitas }}\end{array}$ & Rasio \\
\hline $\begin{array}{l}\text { Profitabilitas }\left(\mathrm{X}_{3}\right) \text { merupakan } \\
\text { rasio yang mengukur } \\
\text { kemampuan perusahaan untuk } \\
\text { menilai seberapa efisien } \\
\text { perusahaan dalam memperoleh } \\
\text { keuntungan atau laba dari setiap } \\
\text { aktivitasnya }\end{array}$ & $\begin{array}{l}\text { Return On Equity (ROE) } \\
\text { merupakan rasio yang } \\
\text { menun-jukkan kemampuan } \\
\text { perusahaan r untuk } \\
\text { menghasilkan laba setelah } \\
\text { pajak dengan menggunakan } \\
\text { modal sendiri yang dimiliki } \\
\text { oleh perusahaan. }\end{array}$ & $\begin{array}{l}\text { ROE } \\
=\frac{\text { EAT }}{\text { Total Ekuitas }}\end{array}$ & Rasio \\
\hline $\begin{array}{l}\text { Nilai Perusahaan (Y) merupakan } \\
\text { sekum-pulan rasio yang } \\
\text { menghubungkan harga saham } \\
\text { suatu perusahaan dengan laba } \\
\text { serta nilai buku per saham, } \\
\text { dimana rasio ini memberikan } \\
\text { indikasi kepada investor dan } \\
\text { mana-jemen sebuah petunjuk } \\
\text { mengenai rancangan perusahaan } \\
\text { di masa lalu dan prospek di masa } \\
\text { mendatang. }\end{array}$ & $\begin{array}{l}\text { Tobin's } Q \text { merupakan rasio } \\
\text { yang digunakan untuk } \\
\text { mengukur rinerja } \\
\text { perusahaan, yaitu dari sisi } \\
\text { potensi nilai pasar suatu } \\
\text { perusa-haan. }\end{array}$ & $\begin{array}{l}\text { Tobin's } Q \\
= \\
\text { Nilai Pasar Aset } \\
\begin{array}{l}\text { Perusahaan } \\
\text { Biaya Pengganti Aset } \\
\text { Perusahaan }\end{array} \\
\text { ((Harga Saham x Jumlah } \\
\text { Saham Beredar)+Total } \\
\text { Hutang))/Total Aset }\end{array}$ & Rasio \\
\hline $\begin{array}{l}\text { Harga Saham (M), merupakan } \\
\text { harga terakhir atau harga } \\
\text { penutupan. }\end{array}$ & $\begin{array}{l}\text { Harga saham yaitu harga } \\
\text { terakhir penutupan yang ada } \\
\text { di papan indeks. }\end{array}$ & $\begin{array}{l}\text { Harga saham }=\text { Closing } \\
\text { Price }\end{array}$ & Rasio \\
\hline
\end{tabular}

\section{Teknik Pengumpulan Data}

Dalam penelitian ini, teknik pengumpulan data yang digunakan adalah metode dokumentasi, yaitu pengumpulan data dengan cara mencari data dan informasi melalui bukubuku, artikel, jurnal, laporan keuangan, media eletronik, karya ilmiah peneliti terdahulu dan lainnya.

\section{Teknik Analisis Data}

Teknik analisis data yang digunakan oleh penulis adalah uji asumsi klasik, analisa deskriptif kualitatif, dan analisa deskriptif kuantitatif. 
Seminar Nasional Penelitian dan Pengabdian kepada Masyarakat

Universitas Sang Bumi Ruwa Jurai Tahun 2020

\section{HASIL DAN PEMBAHASAN}

\section{Hasil Analisis Data}

Dalam penelitian ini, hal yang pertama kali dilakukan adalah menguji asumsi klasik dari data yang digunakan apakah layak atau tidak. Uji normalitas dilakukan berguna untuk mengetahui apakah variabel dependen dan independen yang digunakan dalam penelitian mempunyai distribusi normal atau tidak. Uji normalitas dengan Kolmogorov-Smirnov menunjukkan bahwa data terstandarisasi berdistribusi normal. Uji multikolinieritas ini dilakukan untuk mengetahui ada atau tidaknya hubungan antar variabel bebas. Uji multikolinearitas yang dilakukan dengan melihat TOL (Tolerance) dan VIF (Variance Inflation Factor) menunjukkan bahwa regresi yang terbentuk tidak terjadi gejala multikolinieritas. Uji heteroskedastisitas bertujuan untuk menguji apakah dalam model regresi terjadi ketidaksamaan varian residual dari satu pengamatan ke pengamatan yang lain. Heteroskedatisitas dalam penelitian ini menggunakan metode analisis grafik scatterplot menunjukkan model regresi yang terbentuk dinyatakan tidak terjadi gejala heteroskedastisitas. Uji autokorelasi bertujuan untuk menguji apakah dalam model regresi linear ada korelasi antara kesalahan pengganggu pada periode $\mathrm{t}$ dengan kesalahan penggangu pada periode t-1 (sebelumnya). Uji autokorelasi dilakukan dengan metode Durbin-Watson menunjukkan hasil pengujian autokorelasi tersebut adalah tidak ada korelasi negatif dengan keputusan "no decision".

Langkah berikutnya adalah melakukan analisis deskriptif kualitatif. Berdasarkan data yang diolah dari laporan keuangan PT Delta Djakarta, Tbk yang terdaftar di Bursa Efek Indonesia periode 2009-2019 diperoleh bahwa nilai likuiditas mengalami fluktuasi dan cenderung meningkat. Hal ini disebabkan karena total aset lancar lebih meningkat dibandingkan dengan liabilitas jangka pendeknya yang berasal dari peningkatan kas dan setara kas, piutang usaha, dan persediaan.. Hal ini disebabkan karena liabilitas jangka panjang mengalami penurunan dibandingkan dengan total ekuitas yang mengalami peningkatan yang berasal dari penurunan kewajiban pajak tangguhan dan liabilitas imbalan pasca kerja. Nilai profitabilitas mengalami fluktuasi dan cenderung meningkat. Hal ini disebabkan karena laba bersih setelah pajak mengalami penurunan sedangkan total ekuitas mengalami peningkatan yang berasal dari peningkatan saldo laba, ekuitas yang diatribusikan kepada entitas induk, dan kepentingan non pengendali. Nilai perusahaan mengalami fluktuasi dan cenderung meningkat. Hal ini dikarenakan meningkatnya harga saham, jumlah saham beredar dan total hutang perusahaan di bandingkan dengan total aset.

\section{Uji Hipotesis dengan Uji Simultan (Uji F)}

Uji F dilakukan untuk mengetahui apakah semua variabel independen yang dimasukkan secara bersama-sama (simultan) untuk uji regresi berpengaruh terhadap variabel dependen serta untuk menguji signifikansi koefisien determinasi. Hasil uji $\mathrm{F}$ dalam penelitian ini dapat dilihat pada Tabel 2 .

Tabel 2. Hasil Uji F

\begin{tabular}{rlrrrrr}
\hline Model & & Sum of Squares & df & \multicolumn{1}{c}{ Mean Square } & F & Sig. \\
\hline \multirow{4}{*}{1} & Regression & 27.900 & 3 & 9.300 & 20.229 & $.001^{\mathrm{b}}$ \\
& Residual & 3.218 & 7 & .460 & & \\
& Total & 31.119 & 10 & & & \\
\hline
\end{tabular}

Berdasarkan Tabel 2, hasil uji F yang ditampilkan menunjukan bahwa tingkat signifikasi $0,001<0,05$ maka $\mathrm{H}_{0}$ ditolak, yang berarti bahwa likuiditas, struktur modal, dan profitabilitas 
berpengaruh signifikan terhadap nilai perusahaan pada PT Delta Djakarta, Tbk yang terdaftar di Bursa Efek Indonesia.

\section{Uji Hipotesis dengan Uji Parsial (Uji t)}

Uji t dilakukan untuk menguji signifikan tidaknya pengaruh antara variabel independen terhadap variabel dependen dengan asumsi bahwa variabel lain dianggap konstan secara parsial. Hasil uji t dalam penelitian ini dapat dilihat pada Tabel 3.

Tabel 3. Hasil Uji t

\begin{tabular}{llrrrrr}
\hline Model & \multicolumn{2}{c}{$\begin{array}{c}\text { Unstandardized Coefficients } \\
\text { Standardized } \\
\text { Coefficients } \\
\text { Beta }\end{array}$} & B & Std. Error & t & Sig. \\
\hline & (Constant) & -7.642 & 2.582 & & -2.960 & .021 \\
& CR & -.079 & .101 & -.099 & -.779 & .461 \\
& LTDER & 96.642 & 45.032 & .276 & 2.146 & .069 \\
& ROE & 26.571 & 3.544 & .964 & 7.497 & .000 \\
\hline
\end{tabular}

Dari hasil uji t yang disajikan di atas, dapat diketahui pengaruh variabel independen terhadap variabel dependen. Nilai untuk likuiditas diperoleh nilai signifikansi sebesar 0,461> 0,05 dan nilai struktur modal diperoleh nilai signifikansi sebesar 0,069>0,05 maka berarti likuiditas dan struktur modal tidak berpengaruh terhadap nilai perusahaan pada PT Delta Djakarta, Tbk yang terdaftar di Bursa Efek Indonesia. Sedangkan nilai profitabilitas diperoleh nilai signifikansi sebesar $0,000>0,05$ maka berarti profitabilitas berpengaruh terhadap nilai perusahaan pada PT Delta Djakarta, Tbk yang terdaftar di Bursa Efek Indonesia.

\section{Uji Residual untuk Variabel Moderating}

Uji residual adalah salah satu alat uji yang dapat digunakan dalam mengukur keakuratan variabel dalam memoderasi pengaruh variabel dependen dengan variabel independen. Kriteria dalam penentuan hasil dalam uji residual ini adalah jika nilai koefisien parameternya negatif dan tingkat signifikansinya di bawah 0,05 . Hasil uji residual dalam penelitian ini dapat dilihat pada Tabel 4.

Tabel 4. Hasil Uji Residual

\begin{tabular}{|c|c|c|c|c|c|c|}
\hline & \multirow{2}{*}{ Model } & Unstandardize & Coefficients & \multirow{2}{*}{$\begin{array}{c}\text { Standardized } \\
\text { Coefficients } \\
\text { Beta }\end{array}$} & \multirow{2}{*}{$\mathbf{t}$} & \multirow{2}{*}{ Sig. } \\
\hline & & B & Std. Error & & & \\
\hline \multirow{2}{*}{1} & (Constant) & .514 & .150 & & 3.424 & .008 \\
\hline & $\mathrm{P}$ & $-9.924 \mathrm{E}-007$ & .000 & -.384 & -1.248 & .244 \\
\hline
\end{tabular}

Dari hasil uji t yang disajikan di atas, dapat diketahui bahwa nilai harga saham dalam memoderasi diperoleh nilai koefisien parameternya sebesar -9.924E-007 dan tingkat signifikansi sebesar 0,244>0,05, maka dapat disimpulkan bahwa harga saham tidak mampu memoderasi pengaruh likuiditas, struktur modal dan profitabilitas terhadap nilai perusahaan pada PT Delta Djakarta, Tbk yang terdaftar di Bursa Efek Indonesia.

\section{Evaluasi}

Berdasarkan hasil regresi linier berganda yang telah dilakukan, dapat diketahui bahwa likuiditas dengan parameter Current Ratio (CR) berpengaruh negatif, sedangkan struktur modal dengan parameter Long Term Debt to Equity Ratio (LTDER) dan profitabilitas dengan parameter Return On Equity (ROE) berpengaruh positif terhadap nilai perusahaan dengan menggunakan parameter Tobin's $Q$. Hal ini dapat dilihat dari persamaan regresi berikut :

$$
\hat{\mathbf{Y}}=-\mathbf{7 , 6 4 2}-0,079 \mathrm{X}_{1}+\mathbf{9 6 , 6 4 2 X _ { 2 } + 2 6 , 5 7 1 X _ { 3 }}
$$

Dari hasil tersebut dapat dijelaskan nilai konstanta sebesar $-7,642$ artinya ketika likuiditas, 
struktur modal, dan profitabilitas sama dengan nol maka nilai perusahaan adalah sebesar -7,642 dengan asumsi variabel independen lain sama dengan nol. Variabel likuiditas yang diukur dengan CR berpengaruh negatif terhadap nilai perusahaan sebesar -0.079 yang artinya setiap variabel likuiditas meningkat sebesar 1 satuan, maka nilai perusahaan mengalami penurunan sebesar 0,079 satuan. Sedangkan variabel struktur modal yang diukur dengan LTDER berpengaruh positif terhadap nilai perusahaan sebesar 96,642 yang berarti setiap variabel struktur modal meningkat sebesar 1 satuan, maka nilai perusahaan akan meningkat sebesar 96,642 satuan. Sementara itu, variabel profitabilitas yang diukur dengan ROE berpengaruh positif terhadap nilai perusahaan sebesar 26,571 yang berarti setiap variabel profitabilitas meningkat sebesar 1 satuan, maka nilai perusahaan akan meningkat sebesar 26,571 satuan.

Hasil penelitian koefisien kolerasi dan determinasi diketahui bahwa nilai r sebesar 0,947 artinya terdapat hubungan yang sangat kuat antara likuiditas, struktur modal, dan profitabilitas terhadap nilai perusahaan. Selanjutnya, diperoleh koefisien determinasi $(\mathrm{R})=0,897$, artinya tinggi rendahnya nilai perusahaan sebesar $89,7 \%$ dapat dijelaskan oleh likuiditas, struktur modal, dan profitabilitas, sedangkan sisanya sebesar $10,3 \%$ dapat dijelaskan oleh variabel lain yang tidak dibahas dalam penelitian ini. Sedangkan hasil uji secara simultan diperoleh bahwa likuiditas, struktur modal, dan profitabilitas berpengaruh terhadap nilai perusahaan namun secara parsial likuiditas dan struktur modal tidak berpengaruh terhadap nilai perusahaan pada PT Delta Djakarta, Tbk yang terdaftar di Bursa Efek Indonesia. Hal ini sejalan dengan pendapat (Brigham, 2010) dan sejalan dengan hasil penelitian yang dilakukan (Mohamad Ilham Jaya, 2019) dengan hasil "struktur modal, profitabilitas, dan likuiditas berpengaruh terhadap nilai perusahaan".

\section{KESIMPULAN}

Berdasarkan hasil analisis dan pembahasan yang telah dijabarkan sebelumnya, maka dapat diberikan kesimpulan sebagai berikut:

1. Nilai likuiditas, profitabilitas dan nilai perusahaan mengalami fluktuasi dan cenderung meningkat, sedangkan struktur modal mengalami fluktuasi dan cenderung menurun.

2. Hasil pengujian regresi linier berganda diketahui bahwa likuiditas berpengaruh negatif sedangkan struktur modal, dan profitabilitas berpengaruh positif terhadap nilai perusahaan.

3. Hasil uji F (simultan) menunjukkan bahwa likuiditas, struktur modal, dan profitabilitas berpengaruh signifikan terhadap nilai perusahaan pada PT Delta Djakarta, Tbk yang terdaftar di Bursa Efek Indonesia.

4. Hasil uji t (parsial) diperoleh likuiditas dan struktur modal tidak berpengaruh signifikan terhadap nilai perusahaan, sedangkan profitabilitas berpengaruh signifikan terhadap nilai perusahaan pada PT Delta Djakarta, Tbk yang terdaftar di Bursa Efek Indonesia.

5. Harga saham tidak mampu memoderasi pengaruh likuiditas, struktur modal dan profitabilitas terhadap nilai perusahaan pada PT Delta Djakarta, Tbk yang terdaftar di Bursa Efek Indonesia

\section{DAFTAR PUSTAKA}

Brigham, E. F. dan J. F. H. (2010). Dasar-Dasar Manajemen Keuangan (XI). Salemba Empat.

Hayati, R., Siahaan, Y., Tarigan, P., \& Supitriyani. (2017). PENGARUH LIKUIDITAS DAN LEVERAGE TERHADAP NILAI PERUSAHAAN PADA PERUSAHAAN SUB SEKTOR PROPERTY DAN REAL ESTATE YANG TERDAFTAR DI BURSA EFEK INDONESIA. SULTANIST: JURNAL MANAJEMEN DAN KEUANGAN, 5(2). 
Seminar Nasional Penelitian dan Pengabdian kepada Masyarakat

Universitas Sang Bumi Ruwa Jurai Tahun 2020

https://www.sultanist.ac.id/index.php/sultanist/article/view/97

Horne, James C. Van dan John M. Wachowiccz, J. (2012). Prinsip-prinsip Manajemen Keuangan (Ketigabelas). Salemba Empat.

Margaretha, F. (2011). Manajemen Keuangan Untuk Manajer Non Keuangan. Erlangga.

Mohamad Ilham Jaya. (2019). Pengaruh Struktur Modal, Profitabilitas, Likuiditas, dan Leverage Terhadap Nilai Perusahaan Manufaktur Sektor Aneka Industri [SEKOLAH TINGGI ILMU EKONOMI PERBANAS SURABAYA]. http://eprints.perbanas.ac.id/5080/55/ARTIKEL ILMIAH.pdf

Nainggolan, D. K., Siregar, L., Tarigan, P., \& Supitriyani. (2017). PENGARUH PROFITABILITAS DAN LEVERAGE TERHADAP NILAI PERUSAHAAN PADA PERUSAHAAN SUB SEKTOR KONSTRUKSI DAN BANGUNAN YANG TERDAFTAR DI BURSA EFEK INDONESIA. FINANCIAL (JURNAL AKUNTANSI STIE SULTAN AGUNG), 3(2). https://financial.ac.id/index.php/financial/article/view/59/59

Pardede, R., Siregar, L., Tarigan, P., \& Supitriyani. (2018). PENGARUH LIKUIDITAS DAN PROFITABILITAS TERHADAP NILAI PERUSAHAAN PADA PERUSAHAAN SUB SEKTOR KONSTRUKSI DAN BANGUNAN YANG TERDAFTAR DI BURSA EFEK INDONESIA. SULTANIST: JURNAL MANAJEMEN DAN KEUANGAN, 6(1). https://sultanist.ac.id/index.php/sultanist/article/view/119/118

Rudianto. (2013). Akuntansi Manajemen Informasi Untuk Pengambilan Keputusan Strategis. Erlangga.

Sudana, I. M. (2011). Manajemen Keuangan Perusahaan Teori dan Praktik. Erlangga.

Supitriyani. (2018). Dividend Policy and Stock Price to the Company Value in Pharmaceutical Company's Sub Sector Listed in Indonesia Stock Exchange. International Journal of Law and Society, 1(1). http://www.ijlawsociety.org/article/306/10.11648.j.ijls.20180101.13

Supitriyani, Febrianty, Susanti, E., \& Sudirman, A. (2020). Financial Performance Factors Against Firm Value With Stock Prices As Moderating. ProBank: Jurnal Ekonomi Dan Perbankan, 5(1), 13-23. https://www.e-journal.stie-aub.ac.id/index.php/probank/article/view/564

Widoatmodjo, S. (2005). Cara Sehat Investasi di Pasar Modal. PT Elex. Media Komputindo.

Y, F. F., \& Amanah, L. (2018). PENGARUH KINERJA KEUANGAN TERHADAP NILAI PERUSAHAAN DENGAN PENGUNGKAPAN CORPORATE SOCIAL RESPONSIBILITYSEBAGAI VARIABEL PEMODERASI. Jurnal Ilmu Dan Riset Akuntansi, 7(11). http://jurnalmahasiswa.stiesia.ac.id/index.php/jira/article/view/1320 